\title{
Molecular Insights into the Relationships and Biogeography of West Indian Anoline Lizards
}

\author{
CARLA A. HASS, S. BLAIR HEDGES and LINDA R. MAXSON \\ Department of Biology and Institute of Molecular Evolutionary Genetics, Penn State University, \\ University Park, PA 16802, U.S.A.
}

Key Word Index-Anolis; Chamaeleolis; Chamaelinorops; micro-complement fixation; DNA sequencing; mitochondrial genes; albumin; Greater Antilles.

Abstract-The realization that the present day positions of continents and island arcs are a result of continental drift led to the proposal that the extant West Indian fauna reflect an ancient (Cretaceous) land connection between the proto-Antilles and North and South America. Movements of the Antillean islands throughout the Cenozoic are hypothesized to have further fragmented the fauna present on the protoAntilles when it separated from the mainland $70-80$ million years ago. This proposed vicariant origin of the West Indian fauna challenged the previous theory that some or most of the fauna arrived in the Antilles by overwater dispersal from mainland sources. The virtual absence of appropriate fossils in the West Indies has hampered testing these alternative hypotheses for the origin of the present day West Indian fauna.

We present evidence from two types of molecular data, one providing indirect estimates of amino acid sequence divergence for the protein serum albumin, and the other direct DNA sequence information from a mitochondrial ribosomal RNA gene. Our new data provide insights into the origin and relationships of two enigmatic lizard genera, Chamaeleolis and Chamaelinorops, and suggest they are recent derivatives within the genus Anolis. These data, along with molecular data presented elsewhere, strongly implicate an origin by ovenwater dispersal for most of the Antillean vertebrate fauna.

\section{Introduction}

Interest in the origin of the West Indian biota has generated debate over whether the biota originated as a result of the late Cretaceous vicariant event isolating populations when the proto-Antilles moved into the Caribbean or through the overwater dispersal of the ancestors of extant species to these islands at one or more times subsequent to the formation of the West Indies (Rosen, 1976, 1985). The vicariance theory is consistent with the geologic history of the Caribbean region (Pindell and Barrett, 1990) which places the Greater Antilles in an arc between North and South America during the Cretaceous. Break up of this proto-Antillean arc occurred in the late Cretaceous (70-80 million years ago, $\mathrm{Ma}$ ).

A.direct test of these two alternative explanations rests upon the ability to determine the time that sister taxa in the Caribbean and on the mainland last shared a common ancestor. The origin and relationships of the diverse (and highly endemic) herpetofauna of the West Indies have been the focus of numerous studies. These include comparative morphological analyses (Etheridge, 1960; Williams, 1976a,b, 1989; Joglar, 1989), karyotypic (Gorman and Atkins, 1969; Gorman and Stamm, 1975; Bogart, 1981; Hass and Hedges, 1992) and biochemical investigations-including electrophoretic studies (Yang et al., 1974; Gorman and Kim, 1976; Gorman et al., 1980a, 1983; Hedges, 1989a; Burnell and Hedges, 1990; Hedges and Burnell, 1990; Hass, 1991) and immunological studies (Gorman et al., 1980b; Wyles and Gorman, 1980a,b; Shochat and Dessauẹr, 1981; Gorman et al., 1984; Hass and Hedges, 1991). In particular, biochemical investigations have the potential to address this question of mode of origin by providing the required estimates of divergence times through the use of molecules as "clocks" (Wilson et al., 1977).

The recent comparison of published albumin cDNA sequences of several taxa for 
which immunological distances derived from the quantitative immunological technique of micro-complement fixation (MC'F) are available demonstrates that $\mathrm{MC}^{\prime} F$ data are reliable estimates of absolute amino acid replacement (Prager and Wilson, 1992; Hass et al., unpublished observations). With this method of estimating albumin sequence divergence, we also have a robust molecular estimator of time elapsed since species pairs last shared common ancestry-an albumin molecular clock (Maxson, 1992).

The majority of studies of West Indian taxa have not made a strong effort to identify mainland relatives for these groups or to determine times of divergence from mainland taxa. We have obtained molecular data on albumin evolution in diverse vertebrate groups with representatives on both the mainland and in the Greater Antilles. These data strongly support overwater dispersal as the primary mechanism of colonization in the West Indies (Hedges et al., 1992). However there are some instances where the data indicate a vicariant origin, as in the case of some frogs of the genus Eleutherodactylus (Hedges, 1989b; Hass and Hedges, 1991), and the xantusiid lizard, Cricosaura typica (Hedges et al., 1991).

Recent geological evidence from the Caribbean region may provide the explanation for the paucity of ancient lineages among the West Indian biota. The major extraterrestrial bolide impact that marks the end of the Cretaceous and might have led to the extinction of the dinosaurs (Alvarez et al., 1980; Alvarez et al., 1990; Sheehan et al., 1991) has been localized to that region (Bourgeois et al., 1988; Hildebrand and Boynton, 1990; Izett et al., 1991). A catastrophic tsunami and other ecological consequences resulting from such an impact could have destroyed much of the biota existing on the proto-Antilles at that time, particularly groups occupying lowland areas (Bourgeois et al., 1988; Macdougall, 1988; Hildebrand and Boynton, 1990; lzett et al., 1991; Maurrasse and Sen, 1991).

Although the molecular data presently favor a dispersal origin for most of the West Indian biota (Hedges et al., 1992), some groups believed to have had a long history in the West Indies have not been examined, or not examined closely. Such groups include the endemic insectivores (Solenodon), the fresh-water fish (Burgess and Franz, 1989), and the endemic iguanid lizard genera Chamaeleolis (on Cuba) and Chamaelinorops (on Hispaniola). Here we present new molecular data bearing on the origin of these two lizard genera in the West Indies, as well as a reassessment of the relationships of West Indian Anolis.

\section{Materials and Methods}

Locality data for species studied are in the Appendix. When sampled in the field, animals were bled into heparinized capillary tubes and whole blood mixed 1:1 with the tissue preservative PPS (Gorman et al., 1971). In the laboratory, animals were sacrificed by cryothermy, bled, and plasma and red blood cells were separated, then frozen; tissues also were removed and frozen. Voucher specimens will be deposited in the United States National Museum, Smithsonian Institution (USNM).

Micro-complement fixation. Serum albumin was purified and antisera to serum albumin were prepareo according to standard methods (Maxson and Maxson, 1990). Rabbit antisera were titered and pooled in inverse proportion to their titers as determined by MC'F. All assays were carried out as detailed in Maxson and Maxson (1990). Some albumin antisera were gifts from the laboratory of A. C. Wilson (Anolis carolinensis, A. cuvieri). New antisera were prepared to albumin from Leiocephalus schreibersiand Chamaeleolis barbatus. Chamaeolis recently was proposed as the correct spelling of the generic name for this taxon (Frost and Etheridge, 1989), however, this spelling previously was investigated and was found to be incorrect (Garrido and Schwartz, 1967).

Results are reported as immunological distance units (ID), where one ID is approximately equal to one amino acid difference between the albumins compared (Benjamin et al., 1984; Maxson and Maxson, 1986; Prager and Wilson, 1992). A reciprocal data matrix was constructed for West Indian anoline taxa using published data in conjunction with our new data. Data were tested for non-random deviations from perfect reciprocity and the data were corrected by the method of Cronin and Sarich (1975) as appropriate. Phylogenetic trees, based on both raw and corrected albumin IDs, were constructed by two methods, a modified distance Wagner algorithm (Hutchinson and Maxson, 1987), and the neighbor-joining method (Saitou and Nei, 1987). The trees were rooted using Leiocephalus as an appropriate outgroup taxon. This genus is unequivocally outside of the anoline lizards 
based on morphology (Williams, 1988), yet it is one of the closest non-anoline genera based upon immunological comparisons (Hass et al., unpublished data).

DNA sequencing. For sequencing of mitochondrial genes, DNA was obtained from samples of red blood cells, liver, or intestine which were purified as described in Hedges et al. (1991). An approximately 450 bp segment of the 165 ribosomal RNA gene was amplified using the polymerase chain reaction (PCR) with specific primers for each DNA segment and both strands were sequenced as detailed in Hedges et al. (1991). The primers used for both the PCR and sequencing this region of the 16S ribosomal RNA gene were: 5'CTGACCGTGCAAAGGTAGCGTAATCACT-3', 5'-CTCCGGTCTGAACTCAGATCACGTAGG-3'. Sequence data were read from autoradiograms and aligned by eye (Cabot and Beckenbach, 1989). Nucleotide variation was used to construct trees by the neighbor-joining method (Saitou and Nei, 1987; Studier and Keppler, 1988; Version 2.0), and statistical significance of resultant groups was evaluated by the bootstrap method (Felsenstein, 1985) with 2000 iterations as advocated by Hedges (1992).

Results and Discussion

West Indian biogeography

A recent study (Hedges et al., 1992) to distinguish between vicariance and dispersal as primary mechanisms for the origin of the West Indian biota, employed MC'F data on albumin divergence between pairs of species representing 38 distinct taxonomic groups. In the absence of significant fossil data, the albumin clock was used to provide estimates of divergence times for all pairs of species considered. If species were separated by the movement of the proto-Antilles with the Caribbean plate in the late Cretaceous; all IDs measured between pairs of taxa in the Caribbean and the mainland were expected to fall between 117-133. This is based upon a standard calibration of the albumin clock, using both fossil and geological information for a number of vertebrate groups, where approximately 100 units of ID accumulate every 55-60 million years of lineage separation (Wilson et al., 1977; Maxson, 1992). These comparisons, with all ID values measured less than those expected under the vicariance model, refute a vicariant origin for the majority of the present-day West Indian herpetofauna (Hedges et al., 1992). Indeed, the evidence indicates that multiple (almost continuous) dispersal events have occurred during the last $55 \mathrm{Ma}$.

However, there is evidence that some groups may reflect vicariant events in the West Indies. Biochemical studies of Eleutherodactylus in the West Indies documented a major dichotomy between the subgenera Euhyas and the auriculatus section of the subgenus Eleutherodactylus. This probably occurred when the proto-Antilles broke away from the mainland, isolating Euhyas on Cuba and Eleutherodactylus on Hispaniola (Hedges, 1989b). In West Indian Eleutherodacty/us, however, there is also evidence of subsequent dispersal among the islands and between the West Indies and the mainland throughout the Cenozoic (Hass and Hedges, 1991).

Another instance where species divergence appears to have resulted directly from the rafting of the proto-Antilles in the late Cretaceous became evident from a mitochondrial DNA sequence analysis of relationships among lizards in the family Xantusiidae (Hedges et al., 1991). The monotypic genus Cricosaura, isolated in a remote area of Cuba, is the only xantusiid lizard in the West Indies. All other xantusiids occur in Central America and southwestern North America. Morphological studies concluded that the Middle American genus Lepidophyma was the sister taxon to Cricosaura (Crother et al., 1986).

Collection of living Cricosaura permitted a molecular analysis of relationships among living xantusiids, comparing sequence evolution in two mitochondrial genes$12 S$ ribosomal RNA and cytochrome $b$. For these genes a total of 709 sites were aligned from each of seven taxa. Half of the sites were variable and 168 were informative under conditions of parsimony. The resultant phylogeny showed unequivocally that Cricosaura (1) is the sister taxon to all other xantusiids, and (2) is an ancient taxon, most likely diverging from all other xantusiid lineages in the Cretaceous (Hedges et al., 1991). 
Anolis

The neotropical lizards of the genus Anolis have been the objects of extensive and intensive systematic study for more than a quarter of a century. Some MC'F studies of albumin evolution in the West Indian Anolis have been reported (Gorman et al., 1980b; Wyles and Gorman, 1980a, b; Shochat and Dessauer, 1981; Gorman et al., 1984). The data on Anolis of the Puerto Rico Bank, the Lesser Antilles, and Jamaica are fairly extensive but these earlier studies suffer from a virtual lack of anoline species from Cuba and Hispaniola. Only nine of the 42 Hispaniolan species and only four of the 45 Cuban species of anoline lizards have been compared in MC' $F$ tests.

Field work in both Cuba and Hispaniola (by SBH and associates) provided us with representatives of all series of Anolis occurring on these islands (following Burnell and Hedges, 1990), as well as representatives of the genera Chamaeleolis and Chamaelinorops. With new albumin antisera to Chamaeleolis barbatus, we examined relationships within this genus as well as between this genus and Anolis. Based on osteological data, Chamaeleolis always has been considered to be the most primitive genus of anole in the West Indies (Cannatella and de Quieroz, 1989; Williams, 1989).

Using all available anoline antisera, published data, and tissue samples from approximately one-third of all described species of Anolis, we explored relationships within and between anoline series in the West Indies. Table 1 contains the results of all immunological comparisons available, both from our data and previously published studies. In some instances, more than one 10 is reported between two species. Differences in these IDs are most likely due to different authors using, as antigens, specimens from different populations of a currently recognized species. This may be true for wide-ranging species such as $A$. cristatellus, $A$. carolinensis, etc. which are more likely to have intraspecific variation and may contain cryptic species. Table 2 represents a matrix of mean reciprocal IDs (both uncorrected and corrected) between all species to which antisera were available.

The averages of the reciprocal comparisons were used to construct phylogenetic trees for the taxa (Fig. 1). The standard deviation from reciprocity (Maxson and Wilson, 1975 ) of the raw data is $8.05 \%$ and for the corrected data matrix is $4.81 \%$. The tree constructed from the averages of the raw data using the modified distance Wagner method (Hutchinson and Maxson, 1987) has a standard deviation of $11.6 \%$ (Fitch and Margoliash, 1967) and a standard error of $8.7 \%$ (Prager and Wilson, 1976); for the neighbor-joining tree these values are $8.9 \%$ and $7.5 \%$. For the corrected data using the modified distance Wagner the values are $11.66 \%$ and $8.02 \%$; for the neighbor-joining tree $11.25 \%$ and $9.4 \%$, respectively. These values are similar for trees using both the uncorrected and corrected data because correcting these data did not significantly affect the mean IDs between the taxa and only the mean IDs are used in tree construction. Only the antiserum to $A$. cybotes was consistently biased, underestimating ID.

A striking result of this analysis of albumin evolution is the virtual lack of differentiation seen between Chamaeleolis barbatus and the other three described species of Chamaeleolis (chamaeleonides, guamuhaya, and porcus) examined in this study (Table 1). There are slight but distinct morphological differences between the species examined (Garrido and Schwartz, 1967; Garrido, 1982; Garrido et al., 1991), and the IDs, ranging from 0 to 3 , indicate that they have arisen very recently. This level of variation corresponds to that found within the salamanders of the Plethodon glutinosus complex, a group of closely related taxa which are primarily allopatric in distribution (Highton et al., 1989).

The antiserum to Chamaeleolis barbatus also was used to investigate relationships to other West Indian anoline lizards. Based upon one-way IDs to representatives of all the currently recognized series of West Indian anoles (Burnell and Hedges, 1990), Chamaeleolis is most closely related to members of the cuvieri series, which has 


\begin{tabular}{|c|c|c|c|c|c|c|c|c|c|c|c|}
\hline$\therefore \cdot$ & & & & riola & Jam & Antise & Rico & & & & $C_{a}$ \\
\hline . $\quad \ldots$ & BARB & $C A A^{*} t$ & cerv; & $\mathrm{CrB}^{* 5}$ & VALT & CaIt & EVE*t & pert & BMt & Exr't & GAOI \\
\hline \multicolumn{12}{|l|}{ Cubs : } \\
\hline $\begin{array}{l}\text { Abrecous serios } \\
\text { entecous }\end{array}$ & & 24 & 30 & & & & & & & & \\
\hline \multicolumn{12}{|l|}{ cyanopleorrs } \\
\hline $\begin{array}{l}\text { argillaceus series } \\
\text { argillsceus }\end{array}$ & $\underline{36}$ & $\underline{30}$ & $\underline{36}$ & & & & & & & & \\
\hline caralinonsis series & $\underline{\underline{n}}$ & & & & & & & & & & \\
\hline $\begin{array}{l}\text { allsoni } \\
\text { angusticens }\end{array}$ & & $\frac{9}{34,31}$ & & & - & & & & & & \\
\hline cerolinensts & $\underline{39}$ & 0 & $\underline{49}$ & 64 & 55 & 6 & 51,57 & & 54 & 56,63 & \\
\hline isolepis & & $\underline{13}$ & & & & & & & & & \\
\hline \multicolumn{12}{|l|}{ chamoeteonides seriest } \\
\hline Durbictus: & 0 & $\underline{59}$ & $\underline{22}$ & & & & & & & & \\
\hline $\begin{array}{l}\text { porcus } \\
\text { gcemulares }\end{array}$ & $\frac{0}{1}$ & & $\frac{21}{20}$ & & & & & & & & \\
\hline chamedibonides & $\underline{\overline{3}}$ & & $\underline{\underline{23}}$ & & & & & & & & \\
\hline \multicolumn{12}{|l|}{ equestris series } \\
\hline baracoses & $\underline{45}$ & & & & & & & & & & \\
\hline equestris & & 53,55 & & 48 & 33 & & 48 & & 55 & 48 & \\
\hline inteogutanis & $\underline{47}$ & & & & & & & & & & 48 \\
\hline nobloi & $\frac{\overline{46}}{46}$ & & 35 & & & & & & & & \\
\hline smalmoodi & $\overline{47}$ & & & & & & & & & & \\
\hline \multicolumn{12}{|l|}{ hucius series } \\
\hline $\begin{array}{l}\text { maius } \\
\text { segroiseries }\end{array}$ & $\underline{45}$ & $\underline{46}$ & $\underline{34}$ & & & & & & & & \\
\hline juber. & 31 & & & & & & & & & & \\
\hline mostrei & $\underline{34}$ & & $\underline{50}$ & & & & & & & & \\
\hline sagneri & $\underline{\overline{3}}$ & $\underline{60,65,60}$ & $\underline{50}$ & 57 & 38 & 63 & 54,56 & & 51 & 51 & 36 \\
\hline \multicolumn{12}{|l|}{ Hispaniola } \\
\hline \multicolumn{12}{|l|}{ barbouri series** } \\
\hline barbouri & $\underline{26}$ & $\underline{49}$ & $\underline{20}$ & 25 & & & & & & & \\
\hline \multicolumn{12}{|l|}{ chlorocyanus series } \\
\hline chlorocyanis & $\underline{36}$ & $\underline{50}$ & $\underline{35}$ & 30 & & & & & & & \\
\hline
\end{tabular}


TABLE 1-CONTINUED

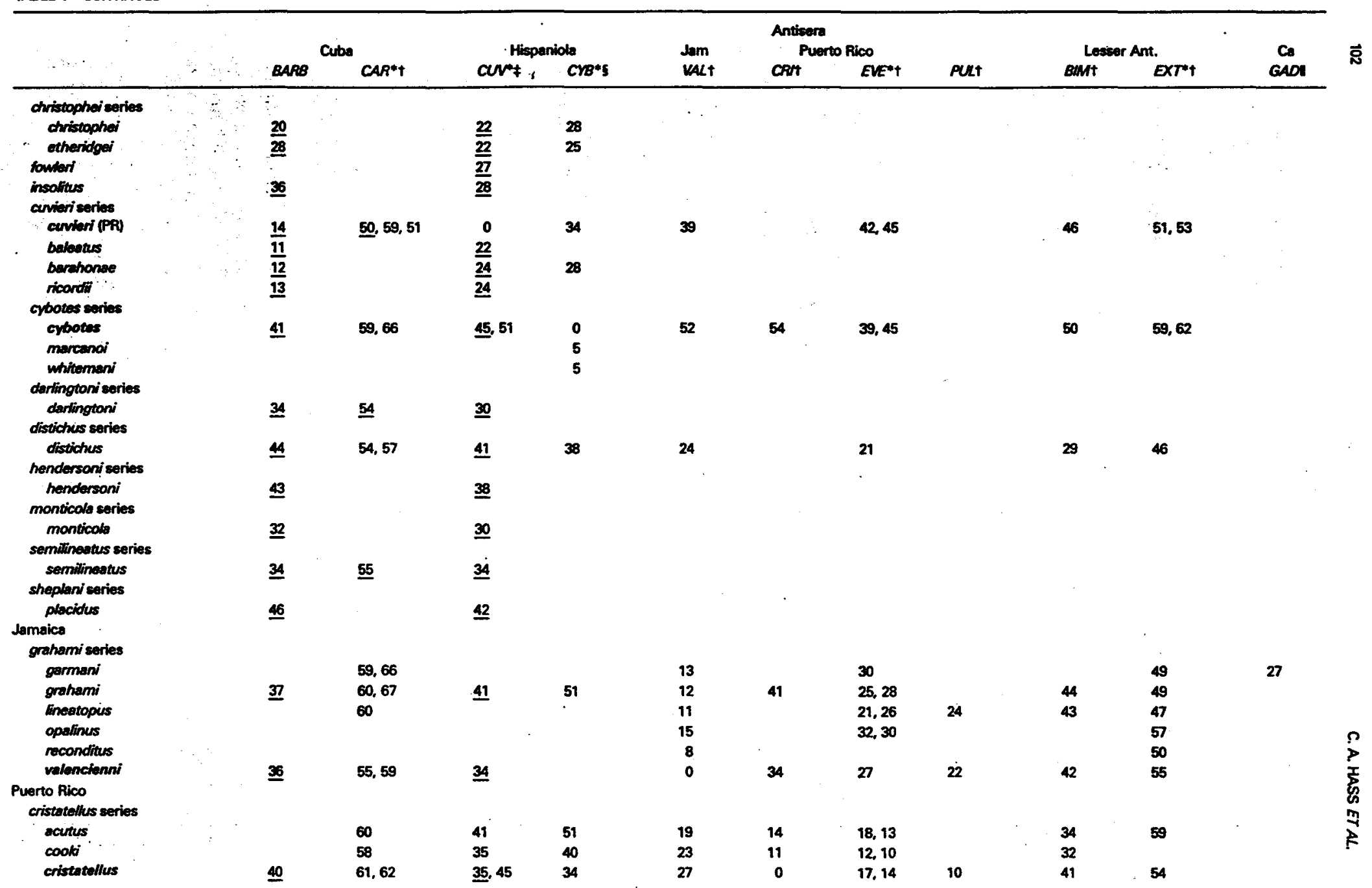




\begin{tabular}{|c|c|c|c|c|c|c|c|c|c|c|c|}
\hline overmanni & $\underline{43}$ & 60,58 & 42,44 & 34 & 27 & 16 & $\mathbf{0}$ & & 33 & 57,59 & 29 \\
\hline gundelochi & & 59 & 45 & 40 & 23 & 13 & 7,16 & 8 & 38 & 47 & \\
\hline krugi & & 61 & 44 & 43 & 21 & 13 & 10,15 & 3 & 36 & & \\
\hline mononsis & & & 46 & 41 & & & 10 & & & & \\
\hline poncensis & & 59 & 41. & 49. & 26 & 13 & 16.14 & & 40 & 59 & \\
\hline pudatiollus. & & 60 & 54 & 46 & 20 & 13 & 7,13 & 0 & 35 & 46 & \\
\hline scriplus & & 61 & 45 & 37 & 24 & 11 & 18,13 & & 41 & 51 & \\
\hline stratuks & & 63 & 47 & $\mathbf{A 2}$ & 28 & 19 & 14,14 & & 41 & 62 & \\
\hline $\begin{array}{l}\text { occerbus series } \\
\text { occumus }\end{array}$ & & & & & & & & & & & \\
\hline $\begin{array}{c}\text { occumus } \\
\text { Losser Antilles }\end{array}$ & 34 & 42 & 41. 36 & 46 & 43 & & 41.49 & & 56 & 51 & \\
\hline \multicolumn{12}{|l|}{$\begin{array}{l}\text { Losser Antilles } \\
\text { Bimecititus serios }\end{array}$} \\
\hline Bimaculoters & $\underline{52}$ & 53,55 & 41 & & 42 & 43 & 35 & & 0 & 59 & \\
\hline forrous & & 53 & & & 40 & 34 & 31 & & 10 & 59 & \\
\hline louchi & & 56 & & & 35 & 39 & 38 & & 10 & 49 & \\
\hline mamoratus & & 54 & & 43 & 44 & 32 & 36 & & 12 & 59 & \\
\hline oculatus & & 56 & 43 & 43 & 41 & 32 & 32,32 & & 11 & 59 & \\
\hline motesi :. & & 45 & & & 40 & 26 & 29 & & 11 & 54 & \\
\hline \multicolumn{12}{|l|}{ roquet series } \\
\hline senous & & 60 & & & 55 & 55 & 57 & & 56 & 3.9 & \\
\hline bonairensis & & 53 & & & 48 & 49 & 56 & & 54 & 20.26 & \\
\hline extremus & & 50,57 & 51 & 42 & 55 & 49 & 41,54 & & 56 & 0 & 53 \\
\hline griseus & & & & & 53 & 49 & & & 55 & 14. & \\
\hline hacioe & & & & & 47 & 49 & & & 53 & 35 & \\
\hline richandf & & 54 & & & 55 & 45 & & . & 54 & 15,12 & \\
\hline roquet & & & & & 57 & 49 & & & 54 & 1,2 & \\
\hline trinitatus & & 57 & & & 57 & 、 & & & 53 & 9,10 & \\
\hline \multirow{2}{*}{\multicolumn{12}{|c|}{ Central America }} \\
\hline frenatus (Panama) & & 52 & & & & & & & & & \\
\hline gandowi (Mexico) & & & & 45 & & & · & & & & 0 \\
\hline \multicolumn{12}{|l|}{ Soutt America } \\
\hline $\begin{array}{l}\text { boettgeiri (Peru) } \\
\text { agassizi (Malpelo) }\end{array}$ & 46 & & 37 & 46 & & 56 & 45,53 & & & & \\
\hline $\begin{array}{l}\text { agassizi (Malpelo) } \\
\text { chrysolepis (Trinidad) }\end{array}$ & & & & 46 & 41 & & 47 & & $\begin{array}{l}58 \\
48\end{array}$ & $\begin{array}{l}35,40 \\
58\end{array}$ & \\
\hline $\begin{array}{l}\text { arysolepis (Trinidad) } \\
\text { innootus (Curagso) }\end{array}$ & & 60 & & & 22 & 34 & 33 & & 43 & $\begin{array}{l}58 \\
51\end{array}$ & \\
\hline $\begin{array}{l}\text { Hinooptuss (Curagsol) } \\
\text { Lolocophe/us }\end{array}$ & 84 & $\begin{array}{l}50 \\
80\end{array}$ & ㄲ1 & & & & & & & & \\
\hline
\end{tabular}

Taxa for which antisera heve been made are indicated in bold. References for published IDs are indicated below. Underlined IDs are those obtained in this study. Wyles and Gorman, 1980a.

tShochat and Dessauer, 1961.

\#Gorman et al., 1980.

sWyles and Gormen 1900 b.

IGorman et ol. 1984.

Treviously placed in the genus Chamaeleolis

**Previousty placed in the genus Chamaelinorops. 
TABLE 2. MEANS OF RECIPROCAL MEASUREMENTS OF ID BETWEEN ANOLIS TAXA FOR WHICH ALBUMIN ANTISERA WERE MADE

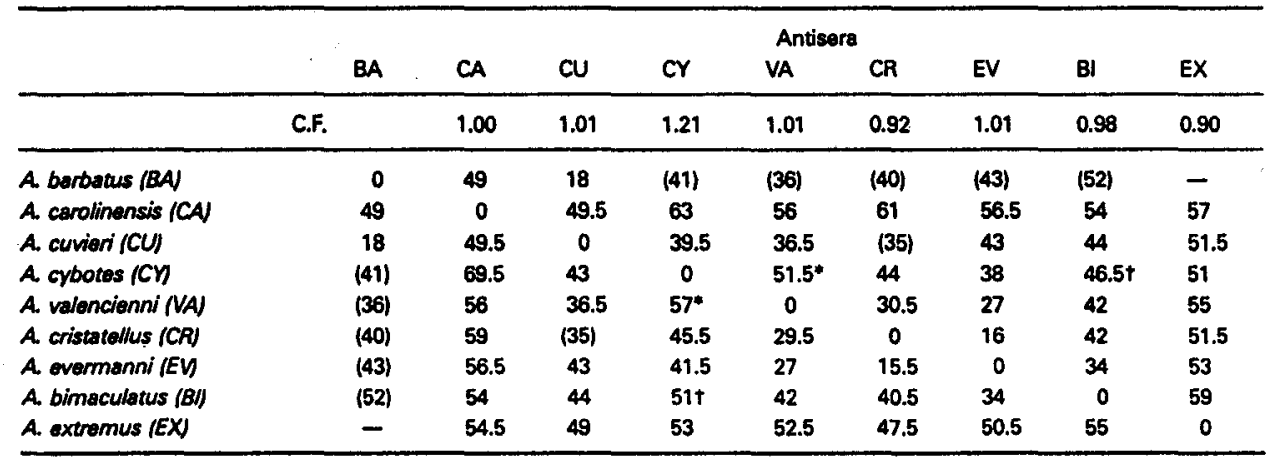

Where there is more than one published ID estimate (see Table 1) an average was used. Mean uncorrected ID values are above the diagonal; mean corrected ID values appear below the diagonal. Correction factors [C.F. (Cronin and Sarich, 1975)] are shown. Numbers in parentheses are one-way values for comparisons in which reciprocal values could not be obtained. The antiserum to $A$. barbsaus could not be corrected because of lack of reciprocal values. A dash indicates that the ID was not available.

"The ID to A. valencienni was not available; therefore, the ID to A. garmani (another member of the grahami series) from A. cybotes was used.

tThe ID to A. bimaculatus was not available; therefore, the tDs to A. marmoratus/A. oculatus lother members of the bimaculatus series) from A. cybotes were used.

representatives on Hispaniola and Puerto Rico. This group of Anolis (Schwartz, 1974) consists of large, stout-bodied species (like Chamaeleolis) that are found primarily in the canopy of trees, whereas Chamaeleolis are the Cuban twig giant anoles. While the osteological data do not suggest a close relationship between these two groups, the immunological data support their close relationship. The mean ID to the four species examined is 12.5. Immunological distances from an antiserum to Anolis cuvieri to other members of the cuvieri series and to all Chamaeleolis species are virtually identical (range 20-24 ID), although slightly higher than the reciprocal measurement, and also support this close relationship. Both the antisera to Chamaeleolis and A. cuvieri also show low IDs to members of the christophei series of Hispaniolan Anolis.

An antiserum to the monotypic genus Chamaelinorops was not available for comparision. However, the one-way IDs available suggest that this taxon falls within the range of IDs measured among West Indian Anolis. This genus is unique among West Indian anolines in showing extreme specialization for terrestrial life (Schwartz and Incháustegui, 1980). However, the morphological data do not unequivocally place this genus outside of Anolis (Etheridge and de Queiroz, 1988). This taxon and Chamaeleolis both show a primitive karyotype (12 macrochromosomes and 24 microchromosomes; Gorman, 1973). However, this karyotype also is found in many Anolis so the data cannot be used to place these taxa outside of a monophyletic Anolis (Cannatella and de Queiroz, 1989). Data on the behavior of male Chamaelinorops also could not determine if this genus is ancestral to or derived from within Anolis (Jensen and Feeley, 1991).

The antiserum to $A$. carolinensis albumin that had been used previously to investigate albumin evolution within West Indian Anolis also was compared to as many members of the Cuban and Hispaniolan series as possible. Previous work with this same antiserum (Shochat and Dessauer, 1981) had not detected a close relationship between this species and any West Indian species, with the lowest ID (42) to the Puerto Rican species $A$. occultus and the highest (67) to the Jamaican species $A$. grahami. Our data show that $A$. carolinensis has its closest relatives on Cuba (ID range 9-34). Two members of the carolinensis group, $A$. allisoni and $A$. porcatus, were close to $A$. 

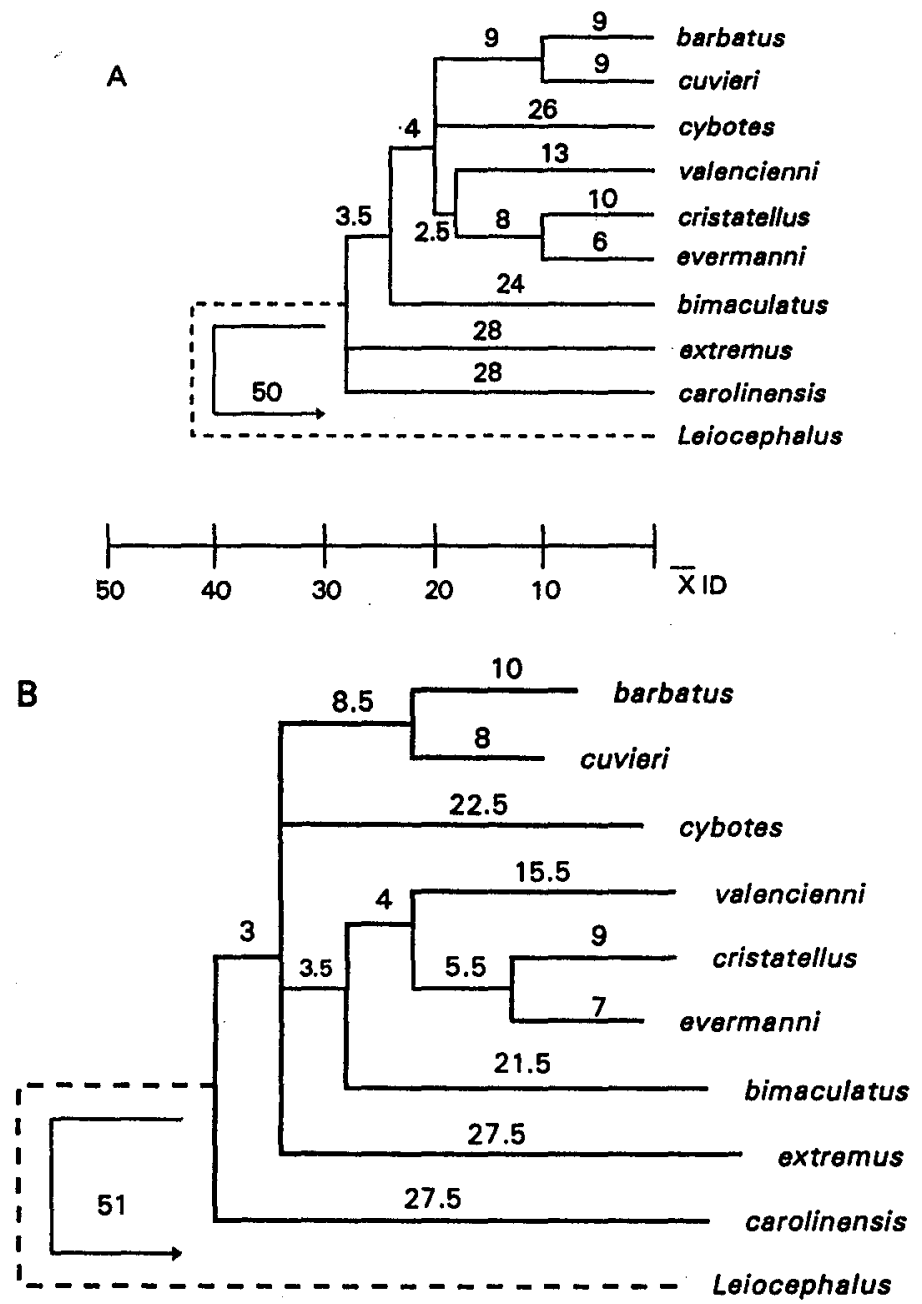

FIG. 1. PHYOOGENETIC TREES BASED ON ALBUMIN IMMUNOLOGICAL DATA FOR NINE SPECIES OF WEST INDIAN ANOLINE LIZAROS. Leiocepha/us schreibersi, a tropidurine lizerd from Hispaniola, was used as the outgroup. Branch lengths greater than 2 (level of experimental error; Maxson and Maxson, 1979) are shown in ID units. (A.) Modified distence Wagner method tree. (B.) Neighbor-joining tree.

carolinensis and equidistant immunologically. The close relationship between $A$. carolinensis and $A$. porcatus also is supported by electrophoretic data (Buth et al., 1980). A third member of the carolinensis group, $A$. isolepis, was slightly more distant. However, A. angusticeps, in the angusticeps group of the carolinensis series, was slightly more distant from $A$. carolinensis than were members of two other Cuban series (alutaceus and argillaceus). The members of the alutaceus series are the closest, with a mean ID of 24 to $A$. carolinensis, while $A$. argillaceus and $A$. angusticeps give mean IDs of 30 and 33 , respectively. The other Cuban series examined (equestris, lucius, and sagrei) and Chamaeleolis give higher IDs to A. carolinensis (46 and above), in the range of those to species from other islands. We also compared the antiserum to A. carolinensis against species representing a number of series on Hispaniola but no close relative was found. Again, the immunological data provide information on series level relationships which could not be resolved using the available electrophoretic data. 


\begin{tabular}{|c|}
\hline 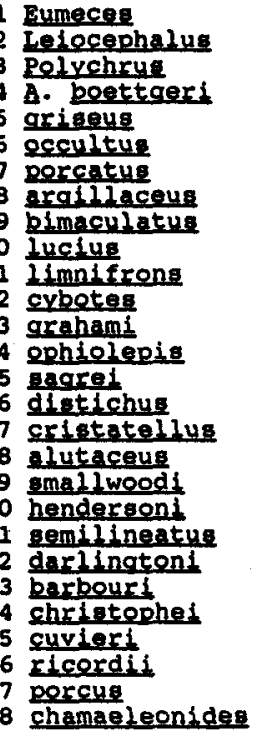 \\
\hline
\end{tabular}

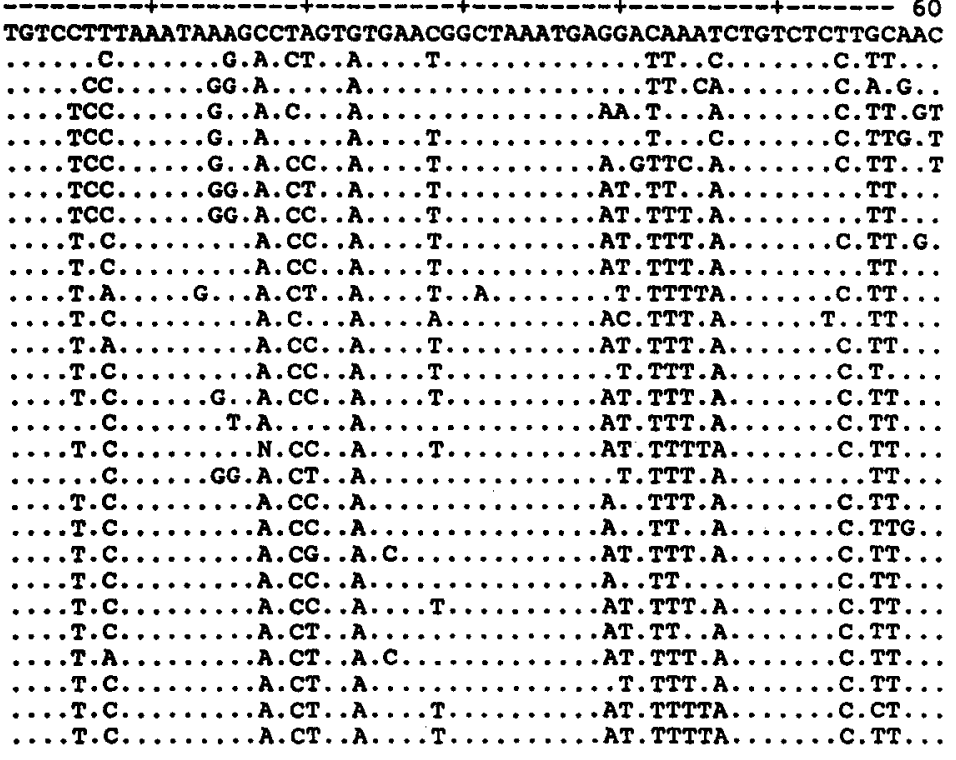

TGTCCTTTARATAAACCCTAGTGTCAACGCCTAAATGAGGACAAATCTCTCTCTTGCA

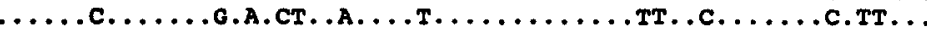

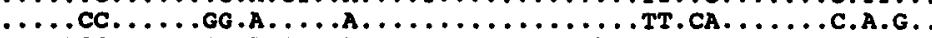

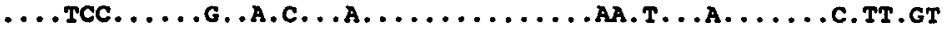

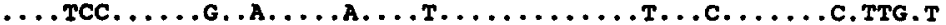

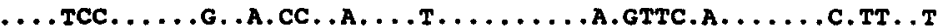

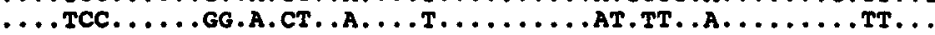

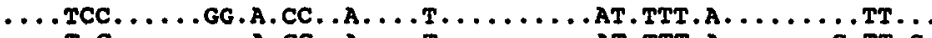

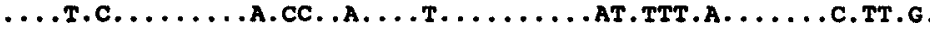

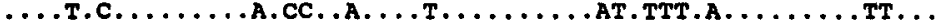

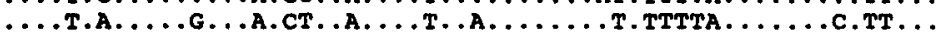

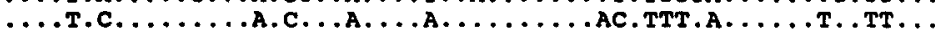

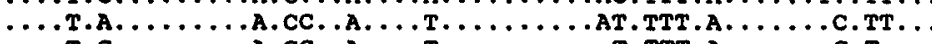

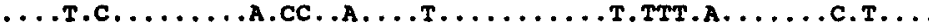

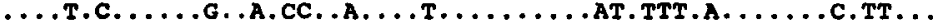

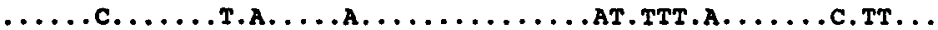

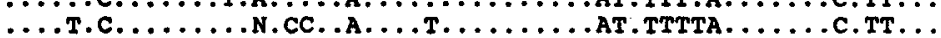

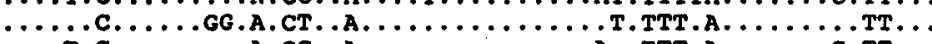

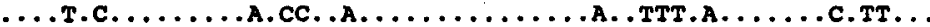
...T.C.........CC.............TT..A......TTG.

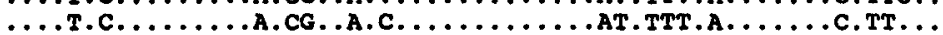

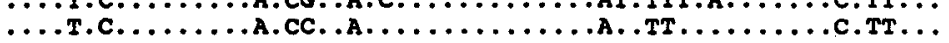

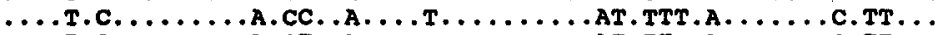

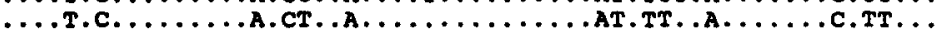

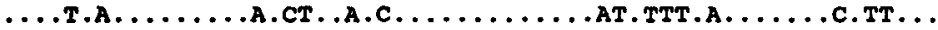

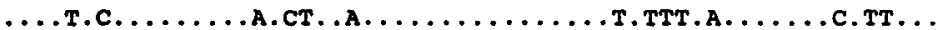

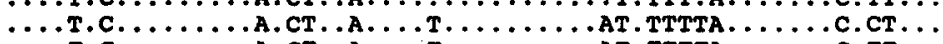

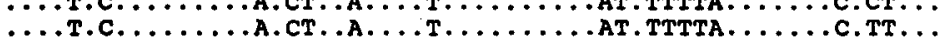

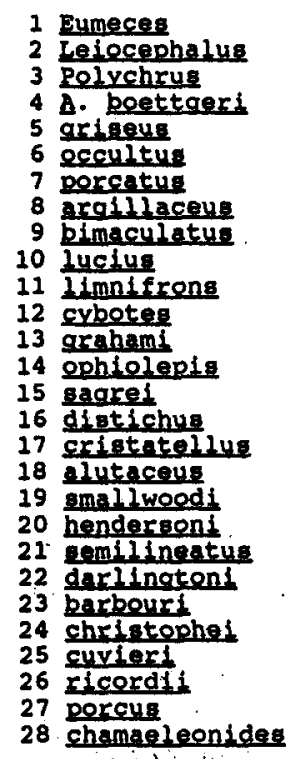

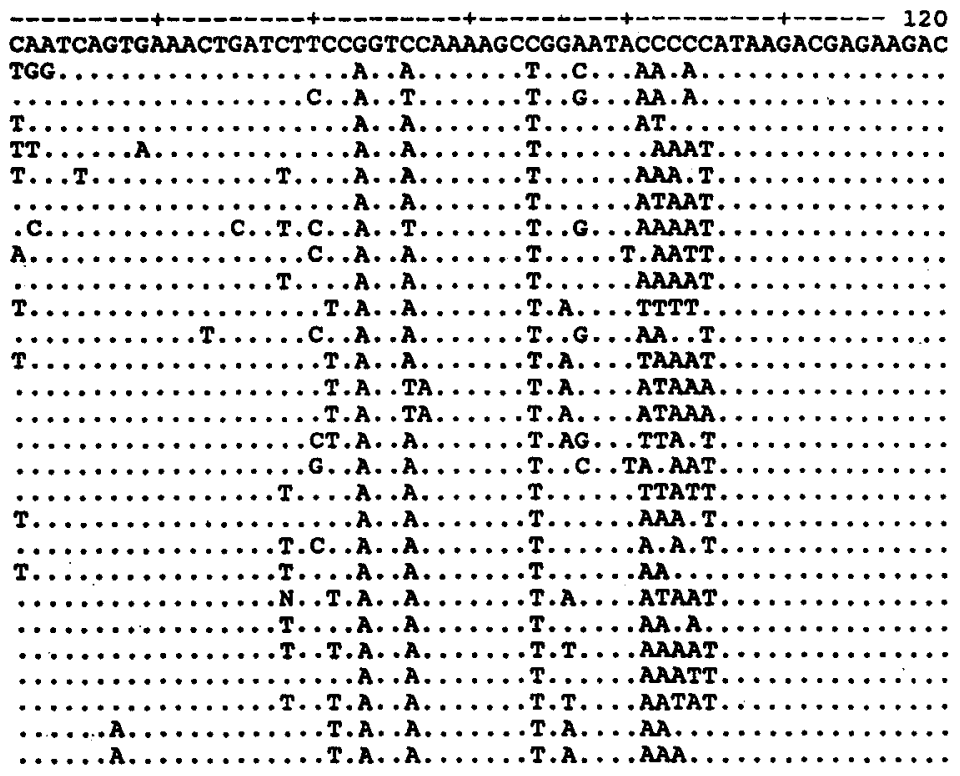

FIG. 2 


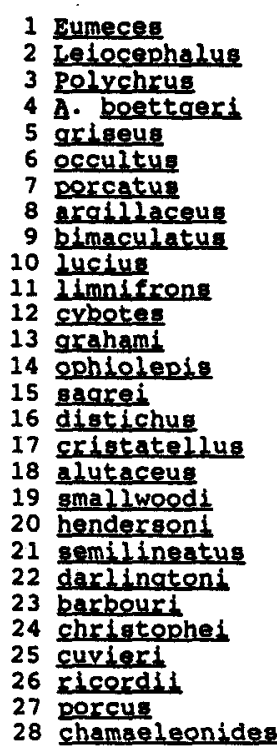

1 Bumeces

2 Leiocephalus

3 polychrue

4 A. boettger:

5 grilseus

6 occultus

7 porcatus

8 argililaceus

9 blimaculatus

10 Luciug

11 Imnifrons

12 cybotes

13 graham

14 ophlolepis

15 sagrel

16 distichug

17 cristatel lus

18 alutaceus

19 smallwood

20 hendersonl

21 semilinestug

22 darlingtont

23 barbour

24 chrigtophe:

25 cuvieri

26 ricordi

27 porcus

28 chameeleanides
CCTGTGGAGCTTCAAACAAACTACTACGTGACACACCAAGGACACAACTAGTAATAAACG .......... . . .TTTTTGT .A.ACAA . ATA.A. . CCT .AC. GTTA. TG . TA. GCA ............ . TT . .AGC. AC. CAC. TCA. . . CACCATA . AC. TGGCCT. CAA $\ldots \ldots \ldots \ldots$. . . . TTTTAAC.A.AA.ATTTT. A. CCT . T.A-.TA-TGGGACTTAA ...A. ..... . T...TTTTAAT.A.A. . TTT. TTTTTAA. . . ACTTA-TG. . A. CTAA ......... T. . TTTTAA. A.GA.AG . T.T-T. . CCTATTC.AA-TG. CC. . AA

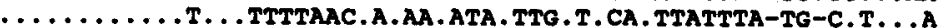
........... . TTTTTA. .ACAA. ATTTTTAT. . AC. ATATTTA-TG-CC. C. AA ......... . . . TTTTAAT. A.AACATT .ATGA. . CA. ACGTTAA-TG . C. . C. AA ......... . . TTtTAAT.A.T. .ATA.TTTAC. CA.ATATTTA-TG.TA...G............. TTTTA..A.A. . ATTT-_...AACATACT.A-TG .TA. . AA ........... TTTTTAC.A.A. . ATTTTTA. C.AA.ATGCCTA-TGC.A. C. AA ......... . . . TTTTTAT. A. A. AAC. TACGT . . AATA . ACTT. -TG. . A. . . AA

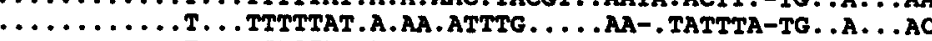

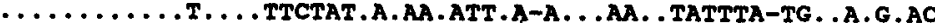
......... . . . TCTTAAC.A.A.A.TTTATA.C.CTTT. . . CTAGTGGGGTTGGA

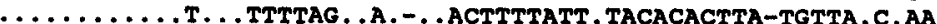
......... . . TTTTACCAAC- . ACG. TTATT. AACATACG .A-TGCTA. C. AA ......... . . . CTTACT.A.AA.ATGCTTTTT. CA.ATATTTA-TG. CCTT.A. $\ldots \ldots \ldots \ldots$............ . . GCC.TACTTA.T.T.TACACTTA-TG . TCCC.G. ......... . . TTT. AA. .A. - . ACTTT. . TCTAA. ATACTTA-TGTCC. T. AA ......... . . . GTTTTAGT. A. AA. TTGCTCATCGCACATATT. A-TG. CA. C. TA $\ldots \ldots \ldots \ldots$. . . . TTTTACC.A.AA. ATAT. TA. C. ACCTTACTTA-TGTTA. TCAA ........ T. . TCT.AGT.A.AA. ATT. ACA. . CATATACT.A-TG. TA. . . ........ . . TTTTAAC.A.AA.T.AT . TA.C.CACATATTTA-TG . TA . . AA

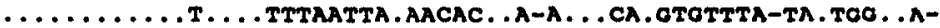
T G TAT A TACCC TTTA T AA G GT TA-TG T .

TTTTGAGTTGGGGCGACTTCGGAAATAAAAAAACTTCCAAGCA-CAGAACCACCAGTTC $\ldots$. . . . . . . . . . . . . . . . . . . . . . . . . . . .

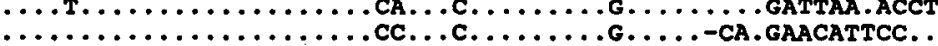

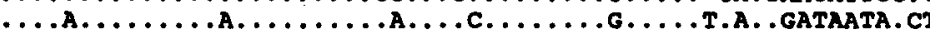

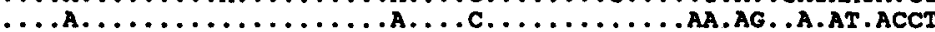
C....................TT...A.......--CT.AAG.A.CGA C...A.........................TG.A.AG.GGC-ACTGC. C.............................A.A.GGC-ACTGC.

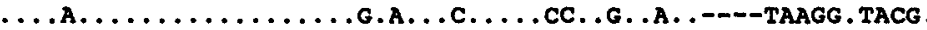

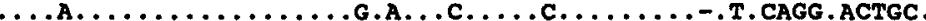
$\ldots$. . .............GCA...CTT..........AAG.C.TTG. TAGC.

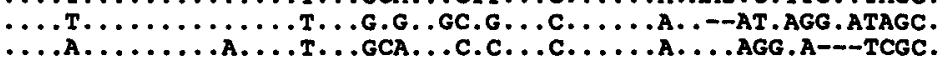
...A.......A...T...G.A.............A..AGAC.AT----G..

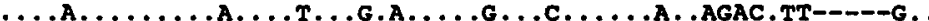

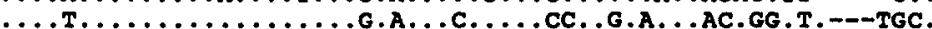

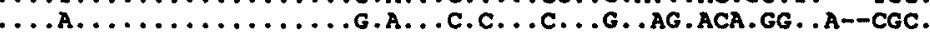

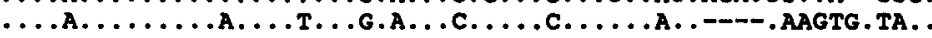

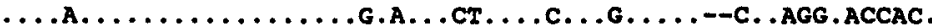

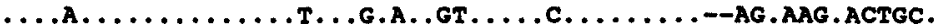
...A.................CCC......G.TA..-A.GAGG.ACACC. C...A................T....CC.G....--.G.AGG..C.G.

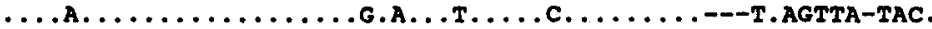
C...A..................TT...............AAGTACTAC. C...A..................T................GGCA..CGC. C..A.................................GAT.A..--C.

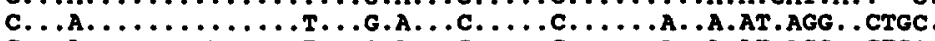
C...A...............................A.AT.AGG..CTGC

FIG. 2 (continued) 


\begin{tabular}{|c|}
\hline 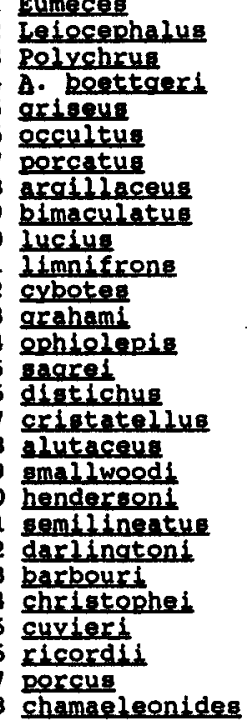 \\
\hline
\end{tabular}

\begin{tabular}{|c|}
\hline 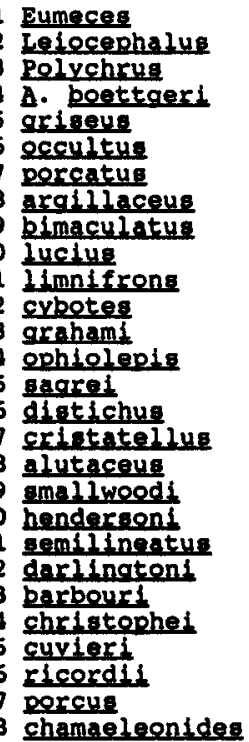 \\
\hline
\end{tabular}

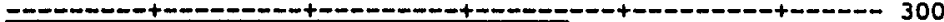
TTACC-AAGACCAACAAGTCAAAGCCTTAAAGCACGACCCAGTAA----CACTGATCAA CA.T. . . . . . . . . . . . . TAA. CTT $\ldots \ldots \ldots \ldots . \ldots \ldots \ldots \ldots$

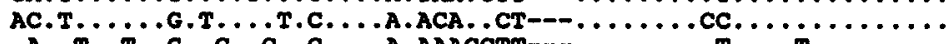

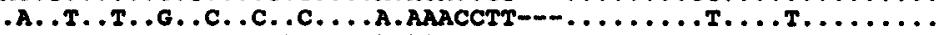

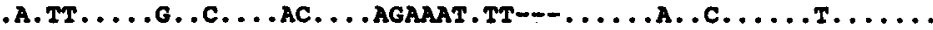

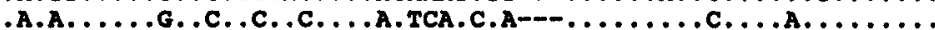

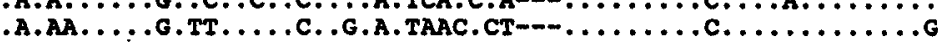

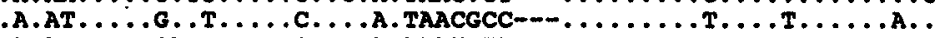

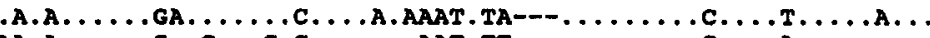
AA.A................-..AAT.TT-.................

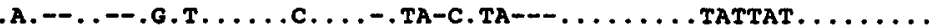

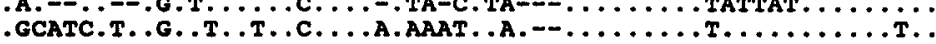

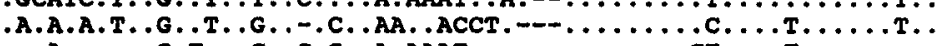

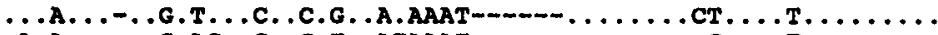
.A.A.....G.AC..C..C.T. .ATAAAT $-\ldots \ldots \ldots \ldots$. . . . . . . CA.AT....G..T.........AAA.C................

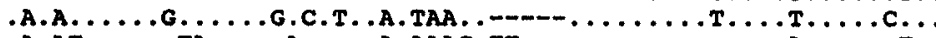
. A. АT . . . TA. . . A. . . A. AAAC. TT- $\ldots \ldots \ldots \ldots \ldots$ A. . . . .

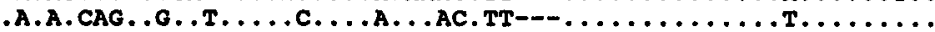
.A. ATTT-. GTTT. .TGAC.C. . . AAAC.TT- $\ldots \ldots \ldots . . . . . \ldots \ldots$

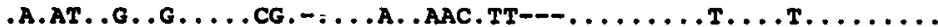

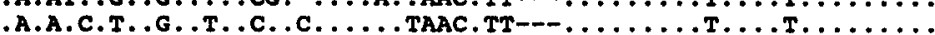

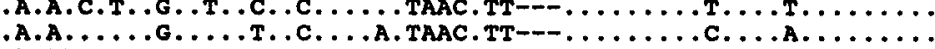

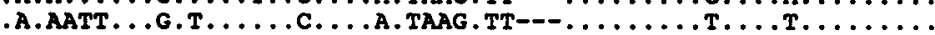

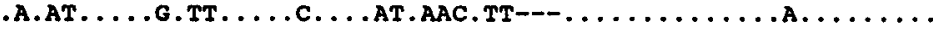

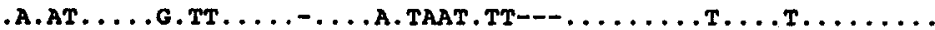

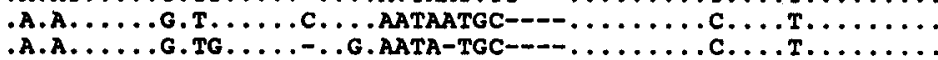

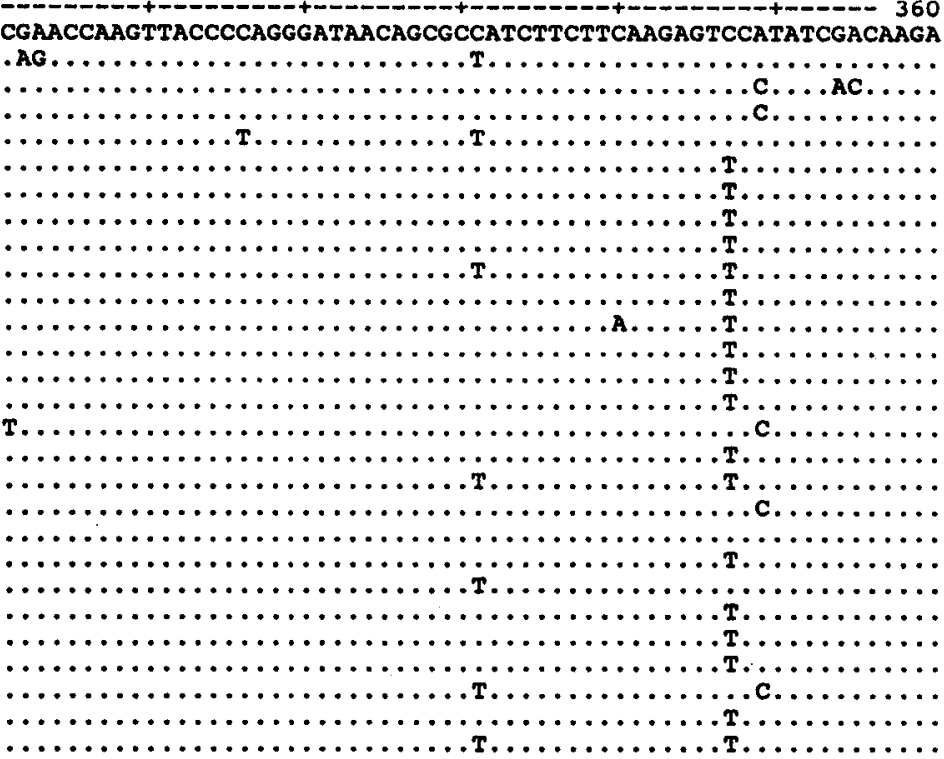

FIG. 2 (continued) 


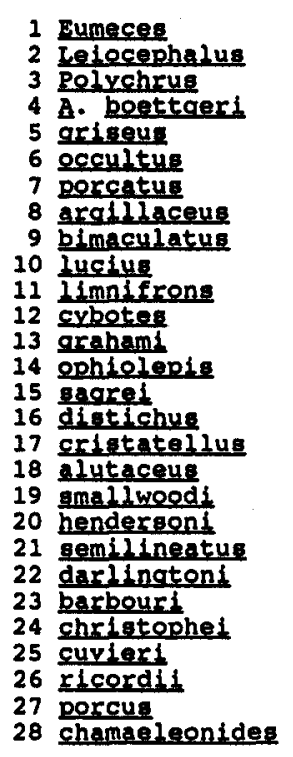

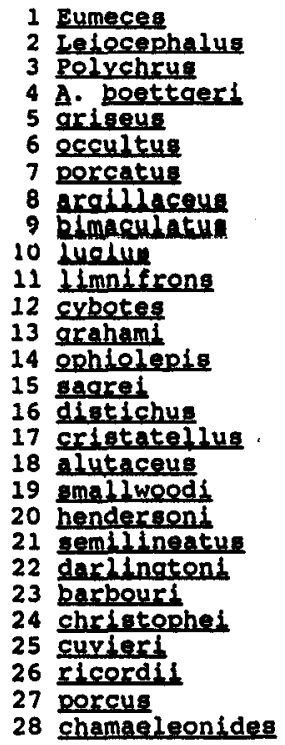

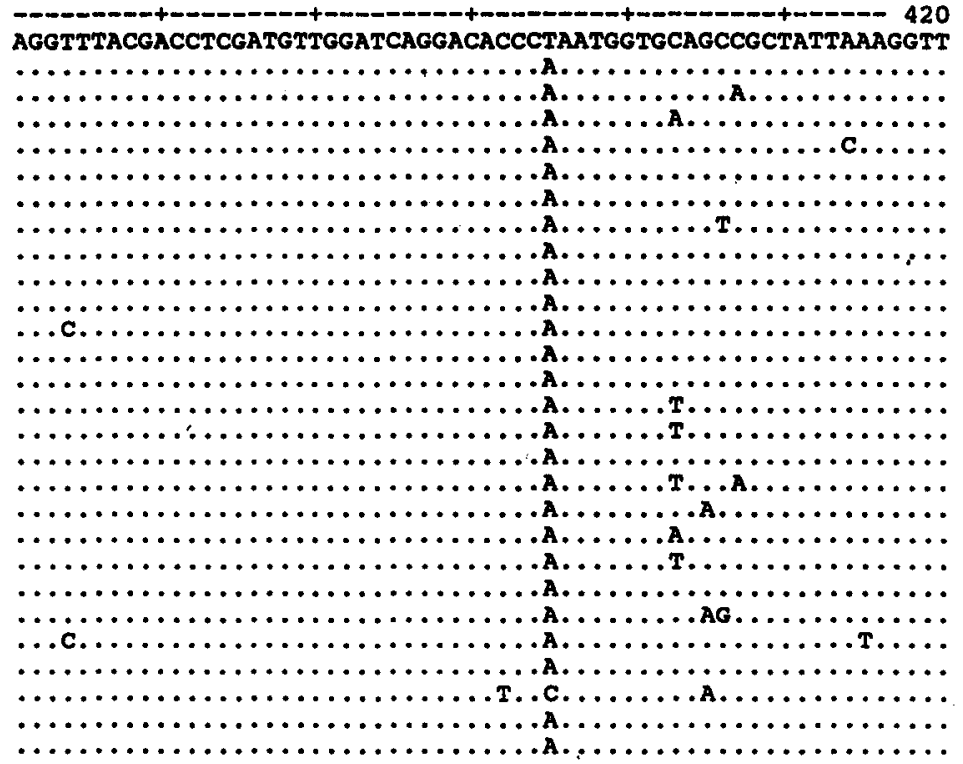

(1) CGTTTGTTCAACGTAGCACAGT .......... ATTA.T. . ............ ATTA..... ................. ... -......... ATTA.... ............ ATTA..... ........... АтTи..... ............. ............. ATTA.T. ........... ATTA. T... ........... ATTA. TC. ............. ...........ATTA.T-.. .................. .......... AGTTA..... ............ ATTA. .... ............TTA.T... ........... ATTA..... ........... ATta.... $\ldots \ldots \ldots \ldots$. . . . . . . ............ ATTA. T... $\ldots \ldots \ldots$ ............. ..........ATTA.T... ............. TTTA. . ........... ATtA.T.

FIG. 2. ALIGNED SEOUENCE DATA OF A 442 BP SEGMENT OF THE MITOCHONDRIAL 16S IRNA GENE FROM 28 LIZARD TAXA. Gaps $(-)$ were inserted to increase sequence similarity; N's denote ambiguities. A solid line sbove the slignment indicates a region not used in the phylogenetic analysis because of uncertain alignment. 


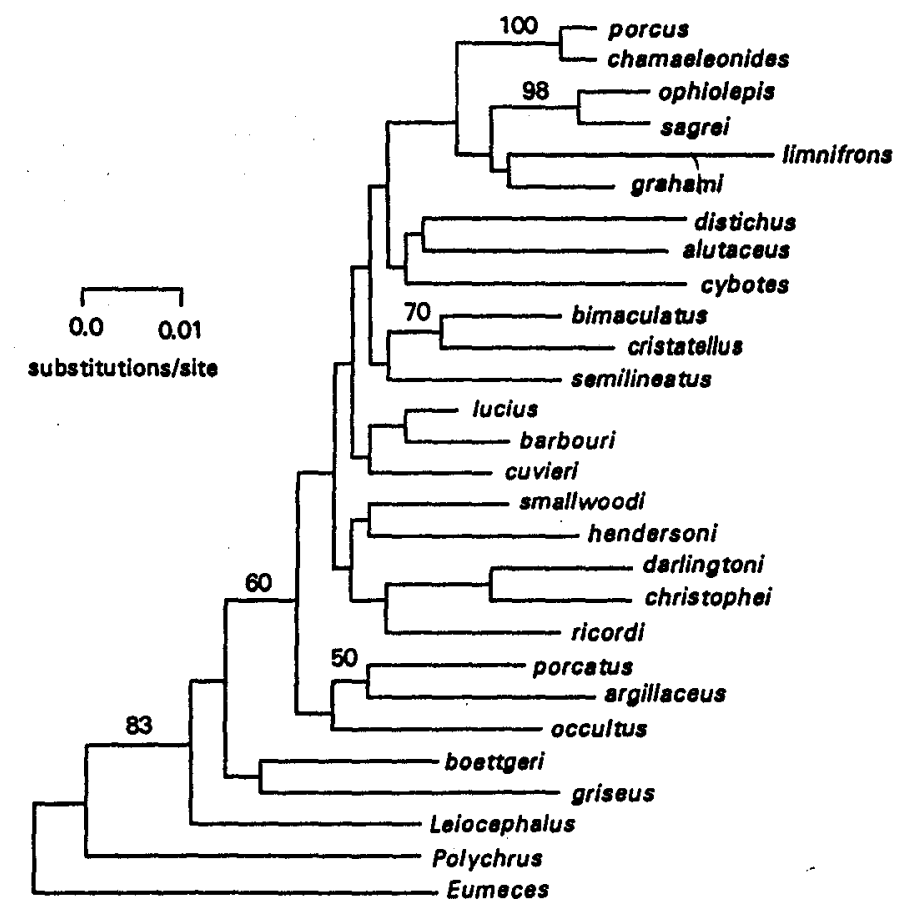

FIG. 3. PHYLOGENETIC TREE OF 28 LIZARD TAXA (Eumeces as OUtgroup) CONSTRUCTED BY THE NEIGHBOR-JOINING METHOD, BASED ON THE DNA SEQUENCE DATA IN FIG. 2. Numbers above the branches indicate confidence limits for groups present in $250 \%$ of the bootstrep trees.

We also obtained data from mitochondrial DNA sequences of 165 ribosomal RNA from two species of Chamaeleolis (chamaeleonides and porcus), Chamaelinorops, 20 West Indian Anolis, one Central American Anolis (limnifrons), one South American Anolis (boettgeri); an anoloid (Polychrus), a tropidurine (Leiocephalus), and a scincid (Eumeces). The aligned sequences are shown in Fig. 2. These data were obtained primarily to give an independent assessment of the placement of Chamaeleolis and Chamaelinorops within Anolis and therefore the 20 West Indian Anolis species (representing 18 of the 21 defined series; Burnell and Hedges, 1990) were included, along with two mainland taxa. A more detailed study involving more taxa and additional genes is in progress. Overall, 442 bp were sequenced in each taxon; of these 352 could be aligned with confidence, resulting in 119 variable sites for analysis.

A neighbor-joining tree constructed from the sequence data is presented in Fig. 3. The DNA sequence data agree with the immunological data in showing an origin for Chamaeleolis and Chamaelinorops within the genus Anolis. These sequence data do not appear to be sufficient to resolve relationships at statistically significant bootstrap $P$ values. At present, there are only two statistically significant clusters in the tree (Fig. 3). One cluster joins the two species of Chamaeleolis included in the study; the other joins $A$. ophiolepis and $A$. sagrei, two Cuban species that are members of the sagrei series. The cluster of species that includes Chamaeleolis, Chamaelinorops, and all West Indian species (plus the Central American taxon) is supported at the $60 \%$ level.

However, when each of the West Indian species of Anolis is compared individually with Chamaeleolis, Chamaelinorops, A. griseus, A. boettgeri, Leiocephalus, Po/ychrus, and Eumeces in separate (8-taxon) analyses, the two endemic West Indian genera (Chamaeleolis and Chamaelinorops) cluster with the West Indian species at higher bootstrap. $P$ values. All comparisons were above the $50 \%$ level and comparisons with 
10 of the 19 species are at or above the $95 \%$ level: $A$. alutaceus $(91.0 \%), A$. argillaceus (86.5\%), A. bimaculatus (97.3\%), A. christophei (99.8\%), A. cristatellus (97.6\%), A. cuvieri (99.2\%), A. cybotes (97.1\%), A. darlingtoni (92.5\%), A. distichus $(68.5 \%), A$. grahami $(99.0 \%)$, A. hendersoni $(89.0 \%)$, A. lucius $(99.0 \%)$, A. occultus $(86.1 \%), A$. ophiolepis (99.2\%), A. porcatus (82.4\%), A. ricordii (99.0\%), A. sagrei (99.2\%), A. semilineatus $(89.8 \%)$, and $A$. smallwoodi $(93.0 \%)$.

The primary limitation of both data sets (albumin IDs and DNA sequences) is the paucity of mainland species of Anolis. Nonetheless, the agreement of both data sets in the placement of Chamaeleolis and Chamaelinorops within the genus Anolis, and especially the very low immunological distances to West Indian species of Anolis, argues strongly against their taxonomic recognition as distinct genera. Therefore, we place the genera Chamaeleolis Duméril and Bibron, 1837 and Chamaelinorops Schmidt 1919 in the synonymy of the genus Anolis Daudin 1802. We take this action to eliminate a clear case of paraphyly in the genus Anolis. It is possible that a related genus of anole, Phenacosaurus, also may be derived from within the genus Anolis (Williams, 1989) but we are unable to address that question with the present data set. Morphological data do not support the recognition of Chamaelinorops as a valid genus, and Chamaeleolis is supported by only two characters (Frost and Etheridge, 1989).

The low ID values among anoline lizards within the West Indies (Table 1) suggests dispersal as the primary mechanism of colonization of those islands by this group. This is similar to the pattern seen in many other terrestrial vertebrates (Hedges et al., 1992). It is clear from these data that Chamaeleolis and Chamaelinorops, which, largely because of their extreme morphological specialization, have been considered to have diverged early in the history of this group or to have been isolated from other anolines (Williams, 1989) are relatively recent additions to the West Indian anoline fauna.

Acknowledgements-We thank Ronald Crombie, who supplied the specimen of $A$. griseus, Jeremy Jacobs, who supplied the $A$. limnifrons, and Paul Moler, who supplied the Eumeces inexpectatus. We also thank Robert Zink for providing some antisera; Ellen Prager for providing antisera and for many helpful comments; Scott Barolo, Matthew Bouchard, and Laura Liermann assisted with data collection. The following persons provided collecting and export permits: Julio Novo and Gilberto Silva (Cuba); Ernest Lindberg. T. Price, and Lee White (Guantanamo Bay Naval Station); Patrick Fairbairn and Ann Haynes (Jamaica); Gaston Hermatin, Edmund Magny, Paul Paryski, R. Pierre-Louis, and Florence Sergile (Haiti); Sixto and Yvonne Incháustegui (Dominican Republic); Eduardo Cardona (Puerto Rico) and J. Fifi (Guadeloupe). Experimental protocols involving animals were approved by the University of Maryland (R 86039) and Pennsylvania State University (IACUC 1296 and 1418) Institutional Animal Care and Use Committees. This research was supported by grants from the U.S. National Science Foundation (BSR 8307115 to Richard Highton, BSR 8906325 to S.B.H., BSR 8918926 to L.R.M. and S.B.H.).

\section{References}

Alvarez, L. W., Alvarez, W., Asaro, F. and Michel, H. V. (1980) Extraterrestrial cause for the Cretaceous-Tertiary extinction. Science 208, 1095-1108.

Alvarez, W., Asaro, F. and Montanari, A. (1990) Iridium profile for 10 million years across the Cretaceous-Tertiary boundary at Gubbio (Italy). Science 250, 1700-1702.

Benjamin, D. C., Berzofsky, J. A., East, I. J., Gurd, F. R. N., Hannum, C., Leach, S. J., Margoliash, E., Michael, J. G., Miller, A., Prager, E. M., Reichlin, M., Sercar, E. E., Smith-Gill, S. J., Todd, P. E. and Wilson, A. C. (1984) The antigenic structure of proteins: a reappraisal. A. Rev. Immunol. 2, 67-101.

Bogart, J. P. (1981) Chromosome studies in Sminthillus from Cuba and Eleutherodacty/us from Cuba and Puerto Rico (Anura: Leptodactylidae). Royal Ontario Mus. Life Scis. Contrib. 129, 1-22.

Bourgeois, J., Hansen, T. A., Wiberg, P. L. and Kauffman, E. G. (1988) A tsunami deposit at the CretaceousTertiary boundary in Texas. Science 241, 567-570.

Burgess, G. H. and Franz, R. (1989) Zoogeography of the Antillean freshwater fish fauna. In Biogeography of the West Indies: Past, Present, and Future (Woods, C. A., ed.), pp. 263-304. Sandhill Crane Press, Gainesville, Florida.

Burnell, K. L. and Hedges, S. B. (1990) Relationships of West Indian Anolis (Sauria: Iguanidae): an approach using slow-evolving protein loci. Carib. J. Sci. 26, 7-30.

Buth, D. G., Gorman, G. C. and Lieb, C. S. (1980) Genetic divergence between Anolis carolinensis and its Cuban progenitor, Anolis porcatus. J. Herpetol. 14, 279-284. 
Cabot, E. L. and Beckenbach, A. T. (1989) Simultaneous editing of multiple nucleic acid and protein sequences with ESEE. Comput. Appl. Biosci. 5, 233-234.

Cannatella, D. C. and de Queiroz, K. (1989) Phylogenetic systematics of the anoles: is a new taxonomy warranted? Syst. Zool. 38, 57-69.

Cronin, J. E. and Sarich, V. M. (1975) Molecular systematics of the New World monkeys. J. Hum. Evol. 4, 357375.

Crother, B. I., Miyamoto, M. M. and Presch, W. F. (1986) Phylogeny and biogeography of the lizard family Xantusiidae. Syst. Zool. 35, 37-45.

Etheridge, R. (1960) The Relationships of the Anoles (Reptilia: Sauria: Iguanidae): An Interpretation Based on Skeletal Morphology. Ph.D. Dissertation, Univ. of Michigan, Ann Arbor.

Etheridge, R. and de Queiroz, K. (1988) A phylogeny of Iguanidae. In Phylogenetic Relationships of Lizard Families: Essays commemorating Charles L. Camp (Estes, R. and Pregill, G. eds), pp. 283-368. Stanford University Press, Stanford, California.

Felsenstein, J. (1985) Confidence limits on phylogenies: an approach using the bootstrap. Evolution 39, 783-791.

Fitch, W. M. and Margoliash, E. (1967) Construction of phylogenetic trees. Science 155, 279-284.

Frost, D. R. and Etheridge, R. E. (1989) A phylogenetic analysis and taxonomy of Iguanian lizards (Reptilia: Squamata). Univ. Kansas Mus. Nat. Hist. Misc. Publs 81, 1-65.

Garrido, O. H. (1982) Descriptión de una nueva especie Cubana de Chamaeleolis (Lacertilia: Iguanidae), con notas sobre su comportamiento. Poeyana 236, 1-25.

Garrido, O. H., Pérez-Beato, O. and Moreno, L. V. (1991) Nueva especie de Chamaeleolis (Lacertilia: Iguanidae) para Cuba. Carib. J. Sci. 27, 162-168.

Garrido, O. H. and Schwart, A. (1967) Cuban lizards of the genus Chamaeleolis. Quart. J. Florida Acad. Sci. 30, 197-220.

Gorman, G. C. (1973) The chromosomes of the Reptilia, a cytotaxonomic interpretation. In Cytotaxonomy and Vertebrate Evolution (Chiarelli, A. B. and Capanna, E. eds), pp. 349-424. Academic Press, London.

Gorman, G. C. and Atkins, L. (1969) New karyotypic data for 16 species of Anolis (Sauria: Iguanidae) from Cuba, Jamaica, and the Cayman Islands. Herpetologica 24, 13-21.

Gorman, G. C., Buth, D. G., Soulé, M. and Yang. S. Y. (1980a) The relationships of the Anolis cristatellus species group: electrophoretic analysis. J. Herpetol. 14, 269-278.

Gorman, G. C., Buth, D. G., Soule, M. and Yang. S. Y. (1983) The relationships of the Puerto Rican Anolis: electrophoretic and karyotypic studies. In Advances in Herpetology and Evolution (Rhodin, A. G. J. and Miyata, K., eds), pp. 626-642. Mus. Comp. Zool., Harvard, Univ., Cambridge, Massachusetts.

Gorman, G. C., Buth, D. G. and Wyles, J. S. (1980b) Anolis lizards of the eastern Caribbean: a case study in evolution. III. A cladistic analysis of albumin immunological data, and the definition of species groups. Syst. Zool. 29, 143-158.

Gorman, G. C. and Kim, Y. S. (1976) Anolis lizards of the eastern Caribbean: a case study in evolution. II. Genetic relationships and genetic variation of the bimaculatus group. Syst. Zool. 20, 167-185.

Gorman, G. C., Lieb, C. S. and Harwood, R. H. (1984) The relationships of Anolis gadovi: albumin immunological evidence. Carib. J. Sci. 20, 145-152.

Gorman, G. C. and Stamm, B. (1975) The Anolis lizards of Mona, Redonda, and La Blanquilla: chromosomes, reiationships, and natural history notes. J. Herpetol. 9, 197-205.

Gorman, G. C., Wilson, A. C. and Nakanishi, M. (1971) A biochemical approach towards the study of reptilian phylogeny: evolution of serum albumin and lactic dehydrogenase. Syst. Zool. 20, 167-186.

Hass, C. A. (1991) Evolution and biogeography in West Indian Sphaerodactylus (Sauria: Gekkonidae): a molecular approach. J. Zool., Lond. 255, 525-561.

Hass, C. A. and Hedges, S. B. (1991) Albumin evolution in West Indian frogs of the genus Eleutherodactylus (Leptodactylidae): Caribbean blogeography and a calibration of the albumin immunological clock. J. Zool. Lond. 255, 413-426.

Hass, C. A. and Hedges, S. B. (1992) Karyotype of the Cuban lizard Cricosaura typica and its implications for xantusiid phylogeny. Copeia 1992, 563-565.

Hedges, S. B. (1989a) An island radiation: allozyme evolution in Jamaican frogs of the genus Eleutherodacty/us. Carib. J. Sci. 25, 123-147.

Hedges, S. B. (1989b) Evolution and biogeography of West Indian frogs of the genus Eleutherodactylus: slowevolving loci and the major groups. In Biogeography of the West indies: Past Present and Future (Woods, C. A., ed.), pp. 305-370. Sandhill Crane Press, Gainesville, Florida.

Hedges, S. B. (1992) The number of replications needed for accurate estimation of the bootstrap $P$ value in phylogenetic studies. Molec. Biol. Evol. 9, 366-369.

Hedges, S. B., Bezy, R. L. and Maxson, L. R. (1991) Phylogenetic relationships and biogeography of xantusiid lizards, inferred from mitochondrial DNA sequences. Molec. Biol. Evol. 8, 767-780.

Hedges, S. B. and Burnell, K. L. (1990) The Jamaican radiation of Anolis (Sauria: Iguanidae): an analysis of relationships and biogeography using sequential electrophoresis. Syst. Zool. 26, 7-30.

Hedges, S. B., Hass, C. A. and Maxson, L. R. (1992) Caribbean biogeography: molecular evidence for dispersal in West Indian vertebrates. Proceedings of the National Academy of Sciences, U.S.A. 89, 1909-1913.

Highton, R., Maha, G. C. and Maxson, L. R. (1989) Biochemical evolution in the slimy salamanders of the Plethodon glutinosus complex of the Eastern United States. Ulinois Biol. Monographs 57, 1-153. 
Hildebrand, A. R. and Boynton, V. W. (1990) Proximal Cretaceous-Tertiary boundary impact deposits in the Caribbean. Science 248, 843-847.

Hutchinson, M. and Maxson, L. R. (1987) Albumin evolution, paraphyly and the relationships of the Australian frog Megistolotis lignarius (Anura: Limnodynastinae). Syst. Zool. 36, 387-394.

Izett, G. A., Dalrymple, G. B. and Snee, L. W. (1991) ${ }^{10}$ AR/ $/{ }^{30}$ Ar age of Cretaceous-Tertiary boundary tektites from Haiti. Science 252, $1539-1542$.

Jensenn, T. A. and Feely, P. C. (1991) Social behavior of the male anoline lizard Chamaelinorops barbouri, with a comparison to Anolis. J. Herpetol. 25, 454-462.

Joglar, R. L. (1989) Phylogenetic relationships of the West Indian frogs of the genus Eleutherodacty/us. In Biogeography of the West Indies: Past, Present, and Future Woods, C. A., ed.), pp. 371-408. Sandhill Crane Press, Gainesville, Florida.

Macdougall, J. D. (1988) Seawater strontium isotopes, acid rain, and the Cretaceous-Tertiary boundary. Science 239, 485-487.

Maurrasse, F. J.-M. R., and Sen, G. (1991) Impacts, tsunamis, and the Haitian Cretaceous-Tertiary boundary layer. Science 252, 1690-1693.

Maxson, L. R. (1993) Molecular perspectives on tempo and pattern in amphibian evolution. In Advances in Herpetology (Adler, K., ed.). Society for the Study of Amphibians and Reptiles, Ithaca, New York. (in press).

Maxson, L. R. and Maxson, R. D. (1979) Comparative albumin and biochemical evolution in plethodontid salamanders. Evolution 33, 1057-1062.

Maxson, L. R. and Maxson, R. D. (1990) Immunological techniques. In Molecular Systematics (Hillis, D. M. and Moritz, C. eds), pp. 127-155. Sinauer Associates, Sunderland, Massachusetts.

Maxson, L. R. and Wilson, A. C. (1975) Albumin evolution and organismal evolution in tree frogs (Hylidae). Syst. Zool. 24, 1-15.

Maxson, R. D. and Maxson, L. R. (1986) Micro-complement fixation: a quantitative estimator of protein evolution. Molec. Biol. Evol. 3, 375-388.

Pindell, J. L. and Barrett, S. F. (1990) Geological evolution of the Caribbean region; a plate tectonic perspective. In The Geology of North America, volume H. The Caribbean Region (Dengo, G. and Case, J. E., eds), pp. 405-432. The Geological Society of America, Boulder, Colorado.

Prager, E. and Wilson, A. C. (1976) Congruency of phylogenies derived from different proteins. J. Molec. Evol. 9 , 45-57.

Prager, E. and Wilson, A. C. (1993) Information content of immunological distances. Methods in Enzymology (in press).

Rosen, D. E. (1976) A vicariance model of Caribbean biogeography. Syst. Zool. 24, 431-464.

Rosen, D. E. (1985) Geological hierarchies and biogeographic congruence in the Caribbean. Ann. Missouri Bot. Garden 72, 636-659.

Saitou, N. and Nei, M. (1987) The neighbor-joining method: a new method for reconstructing phylogenetic trees. Molec. Biol. Evol. 4, 406-425.

Schwartz, A. S. (1974) An analysis of variation in the Hispaniolan giant anole, Anolis ricordiiDumeril and Bibron. Bull. Mus. Comp. Zool. 146, 89-146.

Schwartz, A. S. and Incháustegui, S. J. (1980) The endemic Hispaniolan lizard genus Chamaelinorops. J. Herpetol. 14, 51-56.

Sheehan, P. M., Fastovsky, D. E., Hoffmann, R. G., Berghaus, C. B. and Gabriel, D. L. (1991) Sudden extinction of the dinosaurs: latest Cretaceous, Upper Great Plains. Science 254, 835-839.

Shochat, D. and Dessauer, H. C. (1981) Comparative immunological study of albumins of Anolis lizards of the Caribbean Islands. Comp. Biochem. Physiol. 68A, 67-73.

Studier, J. A. and Keppler, K. J. (1988) A note on the neighbor-joining algorithm of Saitou and Nei. Molec. Biol. Evol. 5, 729-731.

Williams, E. E. (1976a) West Indian anoles: a taxonomic and evolutionary summary. 1. Introduction and a species list. Breviora 440, 1-21.

Williams, E. E. (1976b) South American anoles: the species groups. Papeis Avulsos de Zoologica Sao Paulo 29, 259-268.

Williams, E. E. (1988) A new look at the Iguania. In Proceedings of a Workshop on Neotropical Distribution Patterns (Heyer, W. R. and Vanzolini, P. E. eds), pp. 429-486. Academia Brasileira de Ciéncias, Rio de Janeiro.

Williams, E. E. (1989) A critique of Guyer and Savage, (1986): cladistic relationships among anoles (Sauria: Iguanidae): are the data available to reclassify the anoles? In Biogeography of the West Indies: Past, Present and Future Woods, C. A., ed.), pp. 433-478. Sandhill Crane Press, Gainesville, Florida.

Wilson, A. C., Carlson, S. S. and White, T. J. (1977) Biochemical evolution. A. Rev. Biochem. 46, 573-639.

Wyles, J. S. and Gorman, G. C. (1980a) The albumin immunological and Nei electrophoretic distance correlation: a calibration for the saurian genus Anolis (Iguanidae). Copeia 1980, 66-71.

Wyles, J. S. and Gorman, G. C. (1980b) The classification of Anolis: conflict between genetic and osteological interpretation as exemplified by Anolis cybotes. J. Herpetol. 14, 149-153.

Yang, S. Y., Soule, M. and Gorman, G. C. (1974) Anolis lizards of the eastern Caribbean: a case study in evolution. I. Genetic relationships, phylogeny, and colonization sequence of the roquet group. Syst. Zool. 23, 387-399. 


\section{Appendix}

Taxa examined in this study. The species to which an antiserum was made are indicated by *. Specimens used only in the sequencing portion of the study are indicated by t. All numbers are SBH (S. Blair Hedges frozen tissue collection) or, if indicated, LM (Linda Maxson frozen tissue collection).

Cuba. ahli (172909)-Sancti Spiritus, Tope de Collantes; allisoni (172476)-Matanzas, ca $10.5 \mathrm{~km}$ NNE Playa Larga at La Boca; allogus (172557)-Pinar del Rio, Soroa; alutaceus (172847-51)-Sancti Spiritus, Tope de Collantes; talutaceus (190318)-Santiago de Cuba; Isabelica; angusticeps (172912)-Sancti Spiritus, $9 \mathrm{~km} \mathrm{~W}$ Trinidad at Rio Guanayara; argillaceus (190003-4)-Guantánamo. Quemados de Sabana; †argillaceus (190159)Guantánamo, Quemados de Sabana; baracoae (190007)-Guantánamo, ca $8 \mathrm{~km}$ S Baracoa; "barbatus (190665) - "Cuba"; chamaeleonides (190666) - "Cuba"; guamuhaya (190668)-"Cuba"; homolechis (172553)Pinar del Rio, Soroa; imias (191255)-Guantánamo, Tacre; isolepis (190514)-Santiago de Cuba, vic. of Pico Cuba; jubar (161950)-Guantánamo Bay U.S. Naval Station; Golf Course; lucius (172861)-Sancti Spiritus, Trinidad; †/ucius (191470)-Santiago de Cuba, $1.5 \mathrm{~km}$ WSW La Tabla; luteogularis (172545)-Pinar del Rio, San Vicente; mestrei (172552)-Pinar del Rio, Soroa; noblei (191376)-Santiago de Cuba, $1.5 \mathrm{~km}$ WSW La Tabla; ophiolepis (161938)-Guantánamo Bay. U.S. Naval Station; Golf Course: porcatus (172542)-Ciudad de La Habana, La Habana; † porcatus (171003)-Guantánamo Bay U.S. Naval Station: Golf Course; porcus (190129)Guantánamo, El Yunque de Baracoa; tporcus (190872)-Guantánamo, 2.9 km S La Tagua; sagrei (172884)Sancti Spiritus, Topes de Collantes; sagrei (LM 2990)-"Florida"; smallwoodi (161939)-Guantánamo Bay U.S. Naval Station; Horse Corral; tsmal/woodi (161983)-Guantánamo Bay U.S. Naval Station; Horse Corral.

Hispaniola. baleatus (103036)-DR: La Vega, $7 \mathrm{~km}$ W of Jayaco; barahonae (102688)-DR: Barahona, 19.5 km SW Barahona; barbouri (160146-55)-DR: Barahona, Tejunde (animal 160146 used for sequencing); chlorocyanus (161619)-DR: Elias Piña, Rio Limpio (CREAR); christophei (161674)-DR: Elias Piña, Rio Limpio (CREAR); cybotes (103071)-DR: La Vega, $7 \mathrm{~km}$ W Jayaco; darlingtoni (103986)-Haiti: Grande'Anse; $11.2 \mathrm{~km} \mathrm{S,} 1.9 \mathrm{~km} \mathrm{E}$ Marché Léon; distichus (161692)-DR: La Vega, 13 km NW La Horma; †distichus (160218)-DR: Barahona, 13.7 km E Canoa; etheridgei (161598-602)-DR: Elias Piña, N slope of Loma Nalga de Maco; fowderi (103029)-DR: La Vega, 13 km NW La Horma; hendersoni (104669)-Haiti: Sud'Est, 15 km SW Seguin; insolitus (167594-95)DR: Elias Piña, N slope of Loma Nalga de Maco; monticola (103626-27)-Haiti: Sud, $13.5 \mathrm{~km}$ N Camp Perrin; placidus (102836-37)-DR: Elias Piña, ca $24 \mathrm{~km} \mathrm{~N}$ Los Pinos; ricordii (103985)-Haiti: Grande'Anse, $1 \mathrm{~km} \mathrm{~N}$ Castillon; semilineatus (103018,20)-DR: La Vega, $13 \mathrm{~km} \mathrm{NW}$ La Horma; tsemilineatus (160395)-DR: Hato Mayor, $22 \mathrm{~km}$ WNW El Valle.

Jamaica. grahami (161134)-St. Mary, 2.9 km NW Port Maria; valencienni (103267)-Trelawny, vic. of Quick Step.

Puerto Rico. cristatellus (104732)-11 km W Ponce; t cristatellus (104688)-Rio Piedras (University of Puerto Rico Campus); cuvieri (LM 2989)-“Puerto Rico"; t cuvieri (192792)-Camabalache State Forest; occultus (172019-21)-near the peak of El Yunque; †occultus (104682)-EI Yunque (near the UPR biology house).

Lesser Antilles. bimaculatus (172625)-St. Kitts \& Nevis: 0.5 km N Boyds; † griseus (056528)-St. Vincent: St. Andrew Parish, $2.6 \mathrm{~km}$ E. Vermont (by road).

Central America. limnifrons-Panama: Bocas del Toro, Isla Popa in Laguna de Chiriqui.

South America. boettgeri (171105)-Peru; Pasco, $0.9 \mathrm{~km} \mathrm{~N}, 2.1 \mathrm{~km}$ E Oxapampa.

North America. carolinensis (161363, 161366)-United States: South Carolina, Jasper Co., near Tillman; carolinensis (LM 2991)-United States: "Louisiana".

Outgroup taxa. "Leiocephalus schreibersi (102721, 102879-80, 102889)-DR: Independencia, Tierra Nueva (animal 102721 used for sequencing) Polychrus marmoratus (LM 1932)-Peru: Cuzco, Cuzco Amazónico; Eumeces inexpectatus (LM 2643)-United States: Florida, Alachua County. 